\title{
BLENDED LEARNING IN STRUCTURE FOR TOEFL® SUBJECT: HOW THE ONLINE MODE SUPPORTS THE ONSITE LEARNING EFFECTIVELY
}

\author{
John Pahamzah \\ University of Sultan Ageng Tirtayasa \\ jpahamzah@gmail.com \\ Serang, Indonesia \\ Rahman Hakim \\ University of Sultan Ageng Tirtayasa \\ rahman@untirta.ac.id \\ Serang, Indonesia
}

\begin{abstract}
This article discusses about the onsite and online mode of learning processes experienced by the students in structure for TOEFL® Subject. It is a case study that aimed to describe how the lecturer prepared the online mode effectively in supporting the onsite learning of the subject. It figured out how the lecturer inventarized the problems found in structure section of TOEFL, and how the students interact with the materials in the online mode.
\end{abstract}

Keywords: blended-learning, onsite \& online mode, structure section of TOEFL

\section{INTRODUCTION}

TOEFL®, Test of English as a Foreign Language, is one of the standardized English proficiency that is considered as the most important in North America. It is designed to measure the English-language ability of people who do not speak English as their first language and who plan to study at colleges and universities in any country that English is the native language, either as undergraduate or graduate students. It is oficially administered by ETS (Education Testing Service). (Rogers, 2011). Institutions, such as IIEF (Indonesia International Education Foundation) that is affiliated in Indonesia, have the license to officially conduct the test by cooperating to the sites around the country e.g. at Pusat Bahasa Untirta.

In a paper-based TOEFL $®$, there is a section where the test items measure the participants' understanding about the structure of English sentences, i.e. section of Structure \& Written Expression. The section measures their understanding about the English grammar and usage. Problems such as independent clause, adjective clauses, participial phrases, appositives, adverb clauses, gerunds and infinitives, verbs, word orders, negative words, etc. are measured in the first part of the section by asking the participants to complete the incomplete sentences. While the second part of the section asks the participants to be able to identify errors such as errors 
with word forms, word choices, parallel structure, pronouns, singular \& plurals, etc. (Rogers, 2011).

Understanding the structure or grammar of any language is essential for becoming a skilled and accurate user of that language. (Swick, 2018). Based on the curriculum of the English department of Untirta, there is a subject entitled Structure for TOEFL® that should be taken by the students during their third semester. By the end of the semester they are expected to have more understandings about the problems around the use of grammar in English. However, there is no relationship between the TOEFL® that is administered by ETS and the subject learned by the students. It is merely part of the cumpolsory subjects of the English Department's curriculum.

There are some problems related to the kinds of question in structure \& written highlighted in the subject syllabus. The students are expected to have mastery on those problems at the end of semester. In the classroom, the lecturer discuss the theories related to the problems during the onsite sessions and give some examples of the problems discussed including the explanations.
However, relying only to the sessions in the classroom is not sufficient enough for students to master the problems. They need more times to practice. They need more opportunities to linkage the theories with the problems they found in practices. They are also need to be accustomed to solve many kinds of problems found in the structure section of the TOEFL.

Edmodo, as a learning management system, has features that enable the lecturer or teacher to create several kinds of quizzes such as multiple choice, fill-inthe blank, close test, true-false, and matching exercises. By creating the online class, the lecturer is able to invite students to create their student accounts and join to thr class using the group code. Either through their laptop/ PC or smartphone the students are able to complete the exercises anytime and anywhere. Thus, blending the onsite with the online learning sessions, using blended learning method, is assumed to be the solution related to the problems.

Tang \& Chaw investigated the students' readiness toward the implementation of blended learning. They conducted the research that aimed to support the higher education in increasing the understanding so that they are able to 
formulate the appropriate strategies for implementing the blended learning approach (Tang \& Chaw, 2013). On the other hand, using facebook as the oline mode sessions Djiwandono (Djiwandono, 2015) conducted the onsite sessions to after they completed the discussion online. They have different perception whether the onsite sessions to be conducted or not.

\section{Concept of Blended Learning}

Blended education is all about: situating learning experiences online or onsite based on the relative strengths and weaknesses of each mode. (Stein \& Graham, 2014) There are diverse definitions used for the terms blended learning and online learning. Allen and Seaman have defined blended learning as a course with $80 \%$ of the content being delivered online, with a blended course being one where $30-79 \%$ of the content is delivered online alongside face-to-face sessions. (Lock' \& Redmond, 2015).

The challenge is that many instructors do not have the skills to design or redesign their face-to-face courses to take advantage of the opportunity provided in an online space for learners to gain a deep conceptual understanding of the content through interaction, engagement, collaboration, and critical thinking.
Learners need multiple cognitive opportunities to connect theory and practice by "engaging in attention, enactment, reflection, critique, adaptation, and articulation" (Lock' \& Redmond, 2015)

According to Bakerson et al (Bakerson, Trottier, \& Mansfield, 2015) the first step that should be considered in designing an online learning environment using best practice, as with any course and setting, is to identify the learning objectives. Once the objectives are established, all learning activities and assessments are derived from them.

\section{RESEARCH METHOD}

It is a case study research that describes how the online learning mode support the onsite learning activities that were completed in a face-to-face learning in the classroom. The research tends to investigate how the lecturer of the subject organized the online and the onsite mode of learning, how he prepared the online materials such as quizzes, and how the students interacted with the materials. In order to obtain the data, the researcher conduct the observation using questionnaire to the students as the research instrument. 


\section{DISCUSSION}

The Onsite Learning Mode of the Subject

Beginning the findings of the research, the researcher reviews about how the lecturer prepared and conducted the learning in the classroom or the onsite mode of learning based on the interview result.

\section{Onsite learning materials}

The lecturer choose some problems related to the skills tested in section 2 of TOEFL as follows to be the materials learned during the onsite learning sessions:

Table 1 List of Problems of Structure section in TOEFL

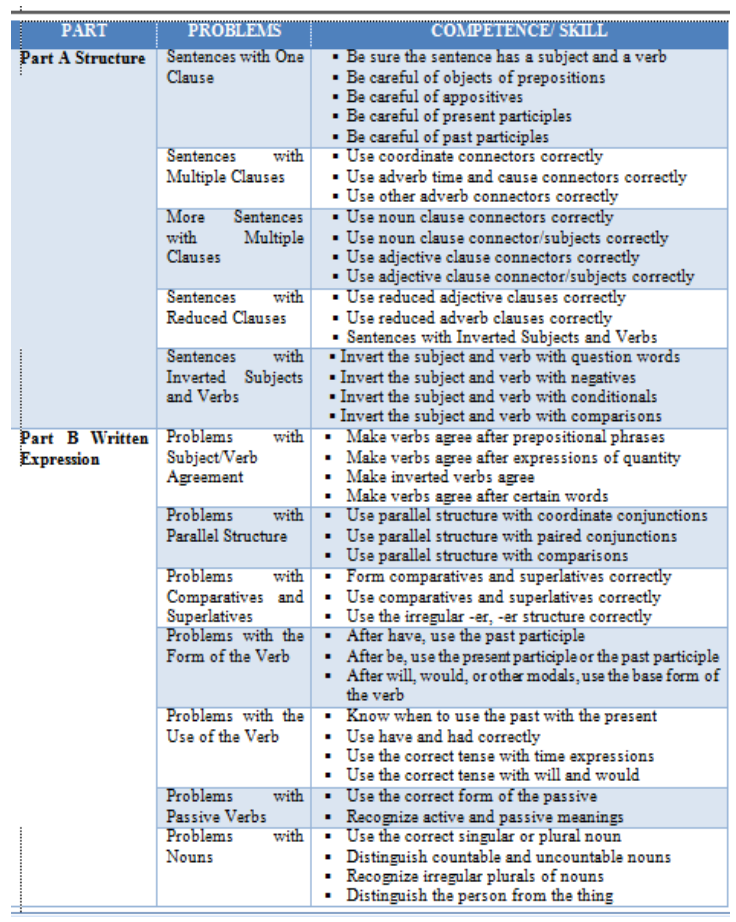

\section{Onsite mode interaction}

Based on the list of the problems above the lecturer made the syllabus and lesson plans for each meeting. He used some method during the onsite sessions in the classroom such as:

1) Lecturing; gave the lectures in the classroom by giving the explanation about the problems including the example covered in the module.

2) Forum Group Discussion (FGD). divided the class into several groups, and each group was given with problems covered in their module, discuss with the group members, and present the result in front of the class.

3) Computer Assisted Language Learning (CALL), installed software of TOEFL Preparation on the computer in language laboraty and asked the students to complete the test provided in the software.

\section{The Online Mode Learning of the}

\section{Subject}

\section{Setting up the online class in edmodo}

In setting up the online class, the lecturer chose Edmodo as the platform of the online mode. He then completed the following steps: 1) Having a teacher account in Edmodo; 2) created a class in 
his Edmodo account named “STRUCTURE4TOEFL 2018”; 3) created some quizzes in the library of the Edmodo; 4) invited students to join the class by giving them the group code; assigned the quizzes periodically; 5) checked the students progress.

\section{The students interaction in the online mode}

Having joined to the online classroom, the students completed some activities through their online classroom such as:

\section{1) Completing pretest}

Through their own account students completed the pretest that was assigned by the lecturer. They were able to check how many items have they done correctly and adversely. The lecturer can check the progress of the students who completed the pretest as shown by the picture below:

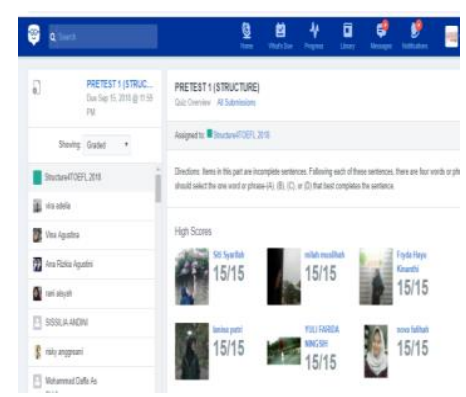

Picture 1 Feature of Edmodo that list students who completed the Pretest

Using the feature above the lecturer checked which students listed as 'graded', 'not graded', and 'not turned in' the quizes. The students can check how many items correct and incorrect

2) Completing the skill quizzes

After having discussion about some problems and skills in Structure section, the students should complete the quizzes related on their Edmodo account. The list of quizzes that the students has completed shown in the picture below:

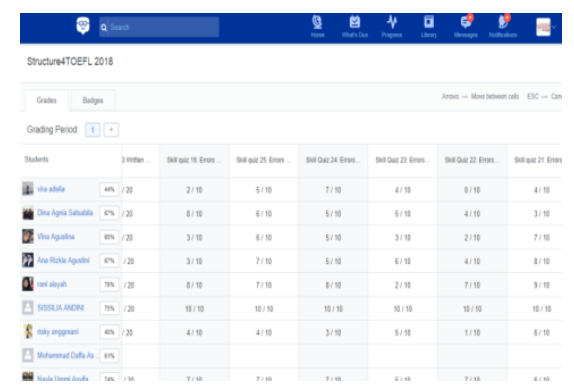

Picture 2 List of Skills completed by each student

After completing the quizzes, the students were able to view the result about what skills they did correctly and which were not. They were also able to view the correct answer of each item so that they 
were able to review and understand the problems.

3. The advantages of the online mode for students

Having interviewed the students, the researcher found that most of the students were satisfied with the quizzes they were working on. They said that the quizzes were very helpful for them because they can understand the ideas in the discussion of the onsite mode session by relating them with the problems they found in each quiz. the feasibility of the online mode in edmodo made them comfortable in completing the test. The length of time and the ubiquity of the application installed in android had them to complete the quizzes anytime and anywhere, without depending on the classroom or onsite session. they have more time to complete the test.

\section{CONCLUSION}

Based on the description of the research findings above, it can be concluded that the lecturer have prepared the onsite mode of learning with the problems he mostly found in structure section of the TOEFL. He then constructed the quizzes based on the indicators of the problems and divided into several skill quizzes to be publish and assign through the online mode of learning. He has selected the Edmodo as the online learning platform. Furthermore, during the onsite mode the researcher used three kinds of method of teaching e.g. by giving the lecture about the theories related to the problems, dividing the class into several forum group discussion, and using CALL method by instaling the software and asking the students do the practices.

On the other hand, the students activities in completing some quizzes related to the problems discussed during the onsite sessions can be concluded as effective for students because the quizzes were helpful for students by relating the theories discussed in the onsite mode with the cases presented in the online mode. the students were able to complete the quizzes anytime anywhere.

\section{References}

Bakerson, M., Trottier, T., \& Mansfield, M. (2015). The Value of Embedded Formative Assessment: An Integral Process in Online Learning Environments Implemented Through Advances in Technology. In S. Koç, X. Liu, \& 
P. Wachira, Assessment in Online and Blended Learning Environments (pp. 3-20). USA: Information Age Publishing Inc.

Djiwandono, P. I. (2015, July). Exploring the Potential of Facebook for Blended Learning. CELT, 15(1), 15-30.

Lock', J. V., \& Redmond, P. (2015).

Empowering Learners to Engage in Authentic Online Assessment. In S. Koç, X. Liu, \& P. Wachira, Assessment in Online and Blended Learning Environments (pp. 2138). USA: Information Age Publishing Inc.

Rogers, B. (2011). The Complete Guide to the TOEFL® Test: PBT Edition. Australia: Heinle Cengage Learning.

Stein, J., \& Graham, C. R. (2014).

Essentials for Blended Learning: A Standards-Based Guide. New York: Routledge.

Swick, E. (2018). English Grammar for ESL Learners: Third Edition. New York: McGraw-Hill Education.

Tang, C. M., \& Chaw, L. Y. (2013, December). Readiness for Blended Learning: Understanding Attitude of University Students. International Journal of Cyber Society and Education, 06(2), 79100. doi:10.7903/ijcse. 1086 